\title{
ULTRAVIOLET-CROSSLINKING REVEALS SPECIFIC AFFINITY OF EUKARYOTIC INITIATION FACTORS FOR SEMLIKI FOREST VIRUS mRNA
}

\author{
BUDDY SETYONO ${ }^{a, *}$, HARRY VAN STEEG ${ }^{b}$ and HARRY O. VOORMA ${ }^{b}$

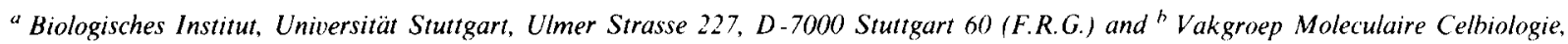 \\ Rijksuniversiteit Utrecht, NL-3584-CH Utrecht (The Netherlands)
}

(Received January 25th, 1984)

Key words: Protein synthesis; Initiation factor; Ultraviolet crosslinking; mRNA: (Semliki Forest virus)

Eukaryotic initiation factors (elF) associate readily with ${ }^{32}$ P-labeled Semliki Forest virus (SFV) mRNA in vitro, forming complexes which can be crosslinked by $254 \mathrm{~nm}$ ultraviolet irradiation. After ribonuclease digestion, the initiation factors were released and analysed by gel electrophoresis. Autoradiography revealed proteins by virtue of crosslinked ${ }^{32}$ P-labeled mRNA fragments. eIF-4A, $-4 B$ and $-4 C$ as well as three subunits of eIF-3 could be crosslinked with SFV mRNA. None of these proteins bound to ribosomal RNAs.

\section{Introduction}

Initiation of protein synthesis in mammalian cells is a complex process in which many components are involved. It proceeds by assembling initiatior tRNA (Met-tRNA ) $_{\text {) }} 40 \mathrm{~S}$ and $60 \mathrm{~S}$ ribosomal subunits and messenger RNA into an $80 \mathrm{~S}$ initiation complex. Various additional proteins, among them the eukaryotic initiation factors (eIFs), are also involved [1-5].

The binding of mRNA to $40 \mathrm{~S}$ subunits is an important early step in which several initiation factors participate. Specific binding of initiation factors to mRNA sequences is thought to play a role in the recognition of messenger and its positioning on the $40 \mathrm{~S}$ ribosomal subunit [6-11]. In previous studies, the nitrocellulose filter technique was employed to demonstrate the mRNA-binding properties of initiation factors [6-10]. Here, we extend the analysis of initiation factor-mRNA interactions using the most direct approach. Ultra-

\footnotetext{
* To whom correspondence should be addressed. Abbreviations: SFV, Semliki Forest virus; eIF, eukaryotic initiation factor; DMSO, dimethyl sulfoxide.
}

violet irradiation of nucleic acid-protein complexes are known to produce covalent linkages between nucleotides and amino acids [12-15]. This method has been used to study intimate and specific RNA-protein interactions both in vivo [16-19] and in vitro [20-23]. A subsequent ribonuclease digestion of the crosslinked complexes releases proteins, some of them carrying covalently bound short nucleotide sequences. If the latter are radiolabeled, the released proteins can be detected autoradiographically after electrophoresis [24].

With this technique, we show here that eIF-3, $-4 \mathrm{~A},-4 \mathrm{~B}$ and $-4 \mathrm{C}$ interact specifically with SFV mRNA in vitro, which is considered a model messenger with cap and poly(A) terminal sequences.

\section{Methods}

Cell culture, radioisotopic labeling and RNA isolation Mouse neuroblastoma cells were grown and infected with wild-type Semliki Forest virus (SFV) as described previously [25,26]. 1h post-infection the inoculum $(10 \mathrm{ml})$ was replaced by $10 \mathrm{ml}$ phosphate-free Eagle's minimum essential medium, supplemented with $3 \%$ calf serum and $1 \mu \mathrm{g} / \mathrm{ml}$ 
actinomycin D to suppress rRNA labeling [27]. $3 \mathrm{~h}$ post-infection $10 \mathrm{mCi}$ carrier-free $\left[{ }^{32} \mathrm{P}\right]$ orthophosphate were added. After $5 \mathrm{~h}$, the ${ }^{32} \mathrm{P}$-labeled viral mRNA was isolated. ${ }^{3} \mathrm{H}$-labeled SFV mRNA was isolated as described previously $[25,26]$.

To obtain ribosomal RNAs, uninfected neuroblastoma cells were also labeled with $10 \mathrm{mCi}$ carrier-free $\left[{ }^{32} \mathrm{P}\right]$ orthophosphate for $5 \mathrm{~h}$ as described above, except that actinomycin $\mathrm{D}$ was omitted. After cell lysis, the RNAs were deproteinized by a phenol/chloroform mixture [28]; thereafter, $28 \mathrm{~S}$ and $18 \mathrm{~S}$ rRNAs were separated by sucrose gradient centrifugation (5-20\% sucrose in a Beckman SW27 Rotor, $22000 \mathrm{rpm}$, for $24 \mathrm{~h}$ at $4^{\circ} \mathrm{C}$ ).

Rabbit reticulocyte elFs. Initiation factors were isolated from rabbit reticulocytes as described previously $[29,30]$. The initiation factors used had the following purities: eIF-2, 50\%; eIF-3, 80\%; eIF-4A, 90\%; eIF-4B, $60 \%$; eIF-4C, $90 \%$; as defined by the ratio of the eIF bands to total protein bands detected by scanning the gel at $300 \mathrm{~nm}$.

Ultraviolet-crosslinking. Samples of $25 \mu 1$ contained: $1 \mu \mathrm{g}{ }^{32}$ P-labeled RNA $\left(2 \cdot 10^{6} \mathrm{cpm}\right) / 10-20$ $\mu \mathrm{g}$ initiation factors $/ 20 \mathrm{mM}$ Tris- $\mathrm{HCl}(\mathrm{pH} 7.6) /$ $100 \mathrm{mM} \mathrm{KCl} / 3 \mathrm{mM} \mathrm{MgAc}_{2} / 7 \mathrm{mM} 2-$ mercaptoethanol $/ 10 \%$ glycerol. Irradiation at 254 $\mathrm{nm}$ was carried out by placing the samples under two $25 \mathrm{~W}$ germicidal tubes at a radiation intensity of $2000 \mu \mathrm{W} / \mathrm{cm}^{2}$, at $0^{\circ} \mathrm{C}$, for $8 \mathrm{~min}$, as described previously $[20,21,23]$. The samples were then treated with ribonuclease $T_{2}$ and ribonuclease $A$ for $1 \mathrm{~h}$ at $37^{\circ} \mathrm{C}[20-23]$. The digestion was stopped by boiling for $3 \mathrm{~min}$. The samples were further analysed by SDS-polyacrylamide gel electrophoresis and subsequent autoradiography (Kodak Xomat, 3 days exposure).

$\mathrm{Cs}_{2} \mathrm{SO}_{4}$-DMSO density gradient centrifugation. Preformed $\mathrm{Cs}_{2} \mathrm{SO}_{4}$-DMSO gradients were prepared as described previously [32]. Irradiated and control samples of ${ }^{3} \mathrm{H}$-labeled mRNA and eIF-3 were diluted with $175 \mu \mathrm{l} 10 \mathrm{mM}$ Tris- $\mathrm{HCl}(\mathrm{pH}$ 7.6) $/ 10 \mathrm{mM} \mathrm{KCl} / 0.01 \%$ Triton $\mathrm{X}-100 / 15 \% \mathrm{v} / \mathrm{v}$ DMSO. They were layered onto $15-50 \% \mathrm{w} / \mathrm{w}$ $\mathrm{Cs}_{2} \mathrm{SO}_{4}$-DMSO preformed gradients in the same buffer and centrifuged in a Beckman SW50 Rotor at $40000 \mathrm{rpm}$ for $20 \mathrm{~h}$ at $20^{\circ} \mathrm{C}$. Thereafter, $200-\mu 1$ fractions were collected. The density of each fraction was determined by weighing $20-\mu 1$ aliquots. The radioactivity was measured from $50-\mu \mathrm{l}$ samples.

\section{Results}

The RNA-protein ultraviolet-crosslinking method recently developed by Greenberg and coworker [20-23] was employed to ligate initiation

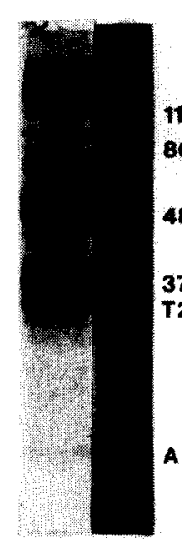

A B

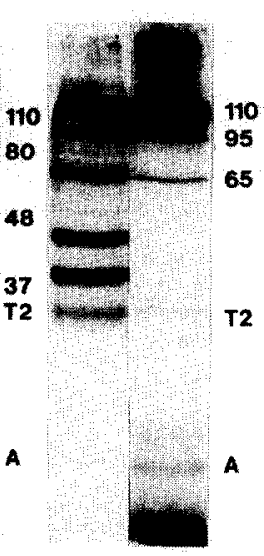

C D

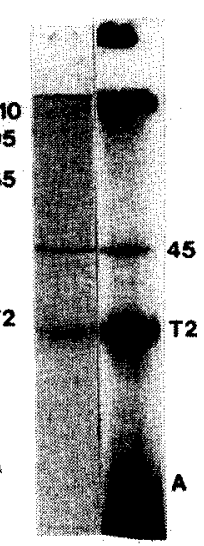

E $F$

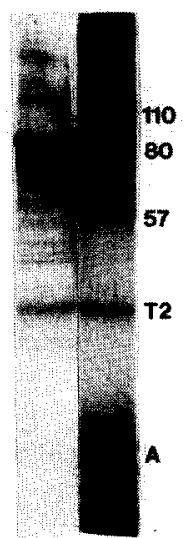

G H

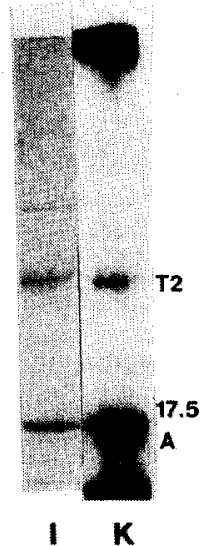

Fig. 1. Ultraviolet crosslinking in vitro of eukaryotic initiation factors and ${ }^{32} \mathrm{P}$-labeled SFV mRNA. $1 \mu \mathrm{g}$ of ${ }^{32} \mathrm{P}$-labeled SFV mRNA $\left( \pm 2 \cdot 10^{6} \mathrm{cpm}\right)$ and $10 \mu \mathrm{g}$ of initiation factors in $10 \mathrm{mM}$ Tris- $\mathrm{HCl} \mathrm{pH}(7.6) / 100 \mathrm{mM} \mathrm{KCl} / 3$ $\mathrm{mM}$ magnesium acetate were irradiated with $254 \mathrm{~nm}$ ultraviolet light for $8 \mathrm{~min}, 2000 \mu \mathrm{W} /$ $\mathrm{cm}^{2}$ in an ice bath followed by ribonuclease digestion and polyacrylamide gel electrophoresis as described in Methods. Lane A; stained gel of eIF-2. Lane $B$; autoradiograph of crosslinked eIF-2. ${ }^{32}$ P-labeled SFV mRNA. Lane C; stained gel of elF-3. Lane D; autoradiograph of crosslinked eIF-3. ${ }^{32}$ P-labeled SFV mRNA. Lane E; stained gel of eIF-4A. Lane F; autoradiograph of crosslinked eIF4A. ${ }^{32}$ P-labeled SFV mRNA. Lane G; stained gel of eIF-4B. Lane $H$; autoradiograph of crosslinked eIF-4B ${ }^{32}$ P-labeled SFV mRNA. Lane I; stained gel of eIF-4C. Lane K; autoradiograph of crosslinked eIF-4C. ${ }^{32} \mathrm{P}$-labeled SFV mRNA. $A=$ ribonuclease $A ; T 2=$ ribonuclease $\mathrm{T} 2$; molecular range is $\times 10^{-3}$. 


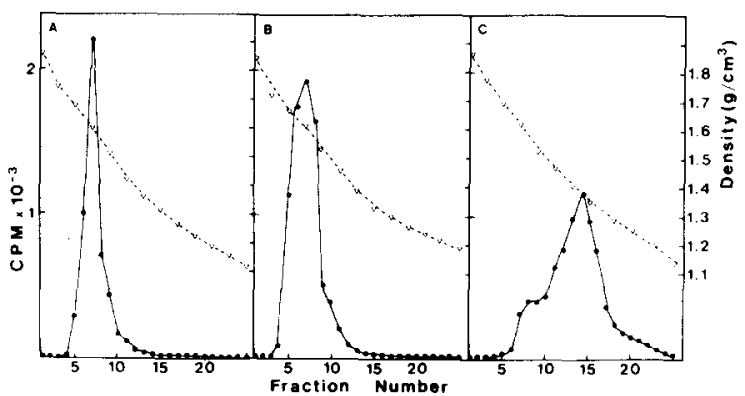

Fig. 2. $\mathrm{Cs}_{2} \mathrm{SO}_{4}$-DMSO density gradient analysis of crosslinked eIF-3 SFV mRNA. Irradiated and control mixtures of $1 \mu \mathrm{g}$ ${ }^{3} \mathrm{H}$-labeled SFV RNA and $10 \mu \mathrm{g}$ elF-3 in $10 \mathrm{mM}$ Tris- $\mathrm{HCl}(\mathrm{pH}$ 7.6) $/ 10 \mathrm{mM} \mathrm{KCl} / 0.01 \%$ Triton $\mathrm{X}-100 / 15 \% \mathrm{v} / \mathrm{v}$ DMSO were layered onto $15-50 \% \mathrm{Cs}_{2} \mathrm{SO}_{4}$-DMSO gradients are as described in Methods. A; ${ }^{3} \mathrm{H}$-labeled SFV mRNA. B; ${ }^{3} \mathrm{H}$-labeled SFV mRNA and eIF-3, not irradiated. $\mathrm{C} ;{ }^{3} \mathrm{H}$-labeled SFV mRNA and eIF-3. irradiated.

factor fractions containing eIF-2, $-3,-4 \mathrm{~A},-4 \mathrm{~B}$ or $-4 \mathrm{C}$ to ${ }^{32} \mathrm{P}$-labeled SFV mRNA. Fig. 1 shows the protein pattern of the individual initiation factor fractions as well as the respective autoradiographs showing bands of protein which could be crosslinked to ${ }^{32}$ P-labeled SFV mRNA.

eIF-3 is a large complex of ten different subunits ranging from $110 \mathrm{kDa}$ to $34 \mathrm{kDa}$ (Fig. 1, lane C) [38-41]. The results of the crosslinking experiment (lane D), shows that only three of them are in direct contact with the SFV mRNA molecule. Their molecular weights of 110000 , 95000 and 65000 correspond to bands of stained gels of the elF-3 sample [41]. $\mathrm{Cs}_{2} \mathrm{SO}_{4}$ density gradient centrifugation analysis shows that the crosslinked eIF-3 mRNA complex bands at a buoyant density of $1.4 \mathrm{~g} \cdot \mathrm{cm}^{-3}$ (Fig. 2C; cf. controls in $\mathrm{A}$ and $\mathrm{B}$ ). This high protein/RNA ratio suggests that it is the entire eIF-3 which binds to SFV mRNA, although obviously only three of its subunits are in direct contact with the mRNA.

eIF-4A, a single polypeptide of $45 \mathrm{kDA}$ [30], can be crosslinked to mRNA, as shown in lanes $\mathrm{E}$ and $\mathrm{F}$ (Fig. 1). eIF-4B is a protein of $80 \mathrm{kDA}$ [10]. The sample, only $60 \%$ pure, showed a band of approx. $80 \mathrm{kDA}$; two additional bands of 110 and $57 \mathrm{kDa}$ (Fig. 1, lanes $\mathrm{G}$ and $\mathrm{H}$ ) are discernable, which may be due to impurities. eIF-4C, a small protein of $17.5 \mathrm{kDa}[42,43]$ could be crosslinked to the mRNA (lanes I and K, Fig. 1).

In contrast, eIF-2, a complex initiation factor
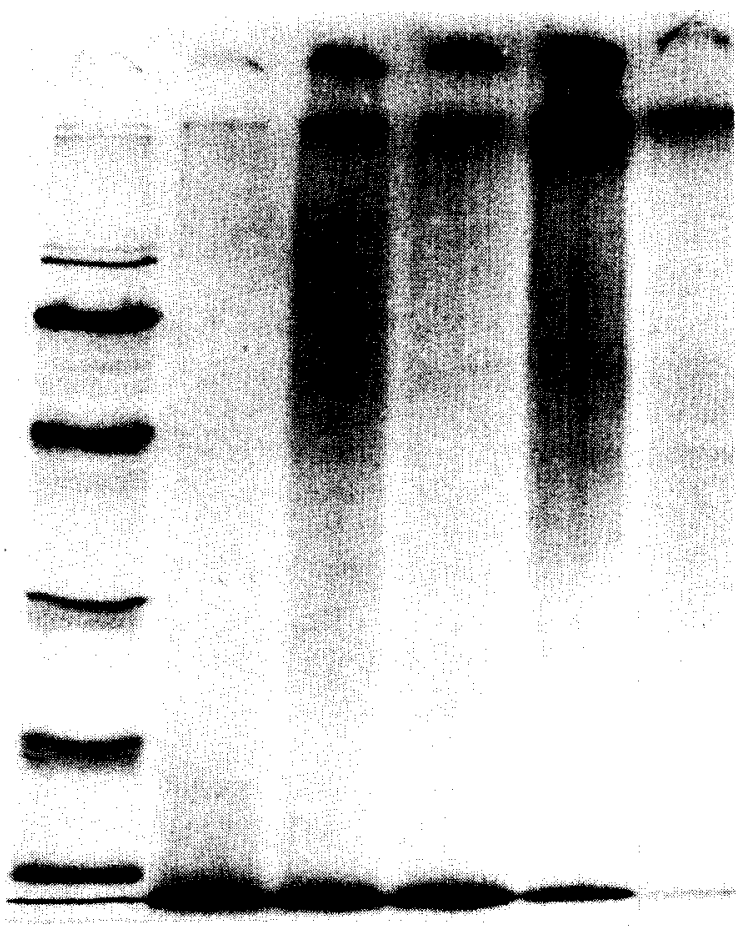

A $B$ C $\quad$ D $\quad E \quad F$

Fig. 3. Autoradiographs of ultraviolet crosslinking in vitro results of eIFs and ${ }^{32}$ P-labeled $18 \mathrm{~S}$ ribosomal RNA.Crosslinking conditions were as described in Methods. Lane $\mathrm{A} ;{ }^{14} \mathrm{C}$. marker proteins (phosphorylase $b$, bovine serum albumin, ovalbumin, carbonic anhydrase, soybean trypsin inhibitor, lactalbumin). Lane B; eIF-2. ${ }^{32} \mathrm{P}$-labeled $18 \mathrm{~S}$ ribosomal RNA. Lane $\mathrm{C}$; eIF-3 ${ }^{32} \mathrm{P}$-labeled $18 \mathrm{~S}$ ribosomal RNA. Lane D; eIF-4A. ${ }^{32}$ P-labeled $18 \mathrm{~S}$ ribosomal RNA. Lane E; elF-4B $\cdot{ }^{32} \mathrm{P}$ labeled $18 \mathrm{~S}$ ribosomal RNA. Lane F; eIF-4C. ${ }^{32}$ P-labeled $18 \mathrm{~S}$ ribosomal RNA. Note. Similar results were obtained with $28 \mathrm{~S}$ ribosomal RNA.

consisting of three polypeptides, could not be crosslinked efficiently (Fig. 1, lanes A and B), although faint bands migrating with the $\alpha$ and $\beta$ subunits of eIF-2 are seen in some experiments.

To ensure that the results presented here were specific for SFV mRNA, we performed control experiments with ${ }^{32} \mathrm{P}$-labeled ribosomal RNA. Fig. 3 shows that no crosslinking occurred between any initiation factor and ribosomal RNAs.

\section{Discussion}

Our experiments indicate that under in vitro conditions the initiation factors eIF-4A, -4B, and 
$-4 \mathrm{C}$ or subunits of elF-3 show affinity for mRNA and bind specifically, because control experiments with ribosomal RNA were negative. eIF-2 did not bind to SFV mRNA convincingly and we are aware of the possibility that initiation factors or their subunits also bind to ribosomes or messenger ribonucleoproteins through protein-protein interactions. Indeed, Westerman et al. [44] were able to crosslink eIF-2 to the ribosomal proteins S 2, S 3 and $S 8$ using a chemical crosslinker, Recently, Kaempfer and co-workers [6-8] reported on formation of equimolar complexes between eIF-2 and mRNA by means of nitrocellulose binding assay. Our results do not support this observation. Since eIF-2 plays its role in the formation of a ternary complex with the initiator Met-tRNA $\mathrm{f}_{\mathrm{f}}$ and GTP and is likely to bind to $40 \mathrm{~S}$ ribosomes before mRNA or messenger ribonucleoprotein are involved [34], it remains questionable whether eIF-2 has mRNA binding activity or even needs it at all.

eIF-3, which was shown to bind to mRNA through its three subunits of 110,95 and $65 \mathrm{kDa}$, has been reported to enhance the binding of MetrRNA $_{f}$ to $40 \mathrm{~S}$ ribosomal subunits. It is required for binding of globin mRNA to $40 \mathrm{~S}$ subunits [34]. Recent data from Vincent et al. [48] showed that globin messenger ribonucleoproteins themselves contain some eIF-3 subunits. This could explain why we were able to crosslink only three of them. Finally, the crosslinking results with eIF-4A, -4B and $-4 \mathrm{C}$ are almost predictable, since they are supposed to promote mRNA binding to $40 \mathrm{~S}$ ribosomal subunits [34].

The idea that some of the elFs (or their subunits) might be identical to messenger ribonucleoproteins is strengthened by our recent observations. Deproteinized mRNA is a poor template in lysates depleted of so-called RNA-binding proteins as compared to the respective messenger ribonucleoprotein form [49,50]; Butcher and Arnstein [52] showed recently that some of the messenger ribonucleoproteins remain attached to the mRNA during translation but it is not clear whether this can be said for any of the initiation factors.

The fact that some eukaryotic initiation factors (or their subunits) have affinity for mRNA again stirs up the question of whether or not some of them are identical to messenger ribonucleoproteins
[45-52], which by definition bind intimately to the messenger. This hypothesis is supported by the observations in a cell-free protein-synthesizing system made up from lysates depleted of so-called RNA-binding proteins. In this system, deproteinized mRNA acts as a poor template, whereas the respective messenger ribonucleoproteins derived from polyribosomes are actively translated and even do not require any additional factors. It is of interest that analysis by one- and two-dimensional-gel electrophoresis reveals bands and spots indicating proteins of similar size and physical properties in initiation factor fractions, polyribosomal messenger ribonucleoprotein and/or RNA-binding proteins. To prove their identities requires more detailed investigation.

\section{Acknowledgements}

We wish to thank Drs. C. van der Mast, M. Salimans, K. Köhler and H.P. Schmid for graciously providing the purified initiation factors and for many helpful discussions; Dr. T. Pederson for his help in editing this manuscript, and Ms. M. Kasperaitis for her skilled technical assistance. This work was supported by an EMBO short-term fellowship (ASTF-3589) and DFG-grant (Se 400/1-1) to B.S.

\section{References}

1 Schreier, M.H., Erni, B. and Staehelin, T. (1977) J. Mol. Biol. 116, 727-753

2 Trachsel, H., Erni, B., Schreier, M.H. and Staehelin, T. (1977) J. Mol. Biol. 116, 755-767

3 Benne, R. and Hershey, J.W.B. (1978) J. Biol. Chem. 253, 3078-3087

4 Safer, B. and Anderson, W.F. (1978) CRC Crit. Rev. Biochem. 261-290

5 Hunt, T. (1980) Trends Biochem. Sci. 5, 178-181

6 Kaempfer, R., Hollender, R., Soreq, H. and Nudel, U. (1979) Eur. J. Biochem. 91, 591-600

7 Rosen, H. and Kaempfer, R. (1979) Biochem. Biophys. Res. Commun. 91, 449-455

8 Kaempfer, R., Van Emmelo, J. and Fiers, W. (1981) Proc. Natl. Acad. Sci. U.S.A. 78, 1542-1546

9 Hellerman, J.G. and Shafritz, D.A. (1975) Proc. Natl. Acad. Sci. U.S.A. 72, 1021-1025

10 Shafritz, D.A., Weinstein, J.A., Safer, B., Merrick, W.C., Weber, L.A., Hickey, E.D. and Baglioni, C. (1976) Nature 261, 291-294

11 Sonenberg, N., Morgan, M.A., Merrick, W.C. and Shatkin, A.J. (1978) Proc. Natl. Acad. Sci. U.S.A. 75, 4345-4348 
12 Smith, K.C. and Aplin, R.T. (1966) Biochemistry 5, 2125-2130

13 Möller, K., Zwieb, C. and Brimacombe, R. (1978) J. Mol. Biol. 126, 489-506

14 Zwieb, C. and Brimacombe, R. (1979) Nucleic Acids Res. 6. 1775-1790

15 Sen, A. and Todaro, G. (1977) Cell 10, 91-99

16 Wagenmakers, A.J.M. Reinders, R.J. and Van Venrooij. W.J. (1980) Eur. J. Biochem. 112, 323-330

17 Setyono, B. and Pederson. T. (1984) J. Mol. Biol. 174. 285-295

18 Mayrand, S., Setyono, B., Greenberg, J.R. and Pederson. T. (1981) J. Cell Biol. 90, 380-384

19 Economidis, I.V. and Pederson. T. (1983) Proc. Natl. Acad. Sci. U.S.A. 80, 1599-1602

20 Greenberg, J.R. (1979) Nucleic Acids Res. 6. 715-732

21 Greenberg. J.R. (1980) Nucleic Acids Res. 8, 5865-5701

22 Greenberg, J.R, and Setyono, B. (1981) Biol. Cell 41, 67-78

23 Setyono, B. and Greenberg, J.R. (1981) Cell 24, 775-783

24 Möller, K, and Brimacombe. R. (1975) Mol. Gen. Genet. 141, 343-355

25 Van Steeg, H., Pranger, M.H., Van Der Zeijst, B.A.M.. Benne, R. and Voorma, H.O. (1979) FEBS Lett. 108, 292-298

26 Van Steeg, H., Thomas, A., Verbeek, S., Kasperaitis, M.. Voorma, H.O. and Benne, R. (1981) J. Virol, 38, 728-736

27 Perry, R.P. (1962) Proc. Natl. Acad. Sci. U.S.A. 48, $2179-2186$

28 Perry, R.P., La Torre, J., Kelley, D.E. and Greenberg, J.R. (1972) Biochim. Biophys. Acta 262, 220-226

29 Thomas, A., Goumans, H., Amesz, H., Benne. R. and Voorma, H.O. (1979) Eur. J. Biochem. 98, 329-337

30 Van Der Mast, C. and Voorma, H.O. (1980) Biochim. Biophys. Acta 60, 512-519

31 Laemmli, U.K. (1970) Nature 227, 680-685

32 Setyono, B., Schmid, H.P. and Köhler, K. (1979) Z. Naturforsch. 34 Teil C, 64-75

33 Safer, B., Adams, S.L., Anderson, W.F. and Merrick, W.C. (1975) J. Biol. Chem. 250, 9083-9089
34 Benne, R., Wong, C., Luedi, M. and Hershey, J.W.B. (1976) J. Biol. Chem. 251, 7675-7681

35 Benne, R., Amesz. H., Hershey, J.W.B. and Voorma, H.O. (1979) J. Biol. Chem. 254, 3201-3205

36 Trachsel. H. and Staehelin, T. (1978) Proc. Natl. Acad. Sci. U.S.A. 75, 204-208

37 Stringer, E.A., Chauduri, A., Valenzuela, D. and Maitra, U. (1980) Proc. Natl. Acad. Sci. U.S.A. 77, 3356-3359

38 Staehelin. T., Erni, B. and Schreier, M.H. (1979) Methods Enzymol. 60, 136-165

39 Benne, R. and Hershey, J.W.B. (1976) Proc. natl. Acad. Sci. U.S.A. 73, 3005-3009

40 Thompson, H.A., Sadnik, I., Scheinbuks, J. and Moldave. K. (1977) Biochemistry 16, 2221-2225

41 Floyd, G.A., Merrick, W.C. and Traugh, J.A. (1979) Eur. J. Biochem. 96, 277-286

42 Goumans, H., Thomas. A., Verhoeven, A., Voorma, H.O. and Benne, R. (1980) Biochim. Biophys. Acta 608, 39-46

43 Thomas, A., Goumans, H., Voorma, H.O. and Benne. R. (1980) Eur. J. Biochem. 107, 39-45

44 Westerman, P., Heumann, W., Bommer, U.A., Bielka, H., Nygard, O. and Hultin, T. (1979) FEBS Lett. 97, 101-104

45 Liautard. J.P. (1977) Biochim. Biophys. Acta 476, 238-252

46 Slegers, H., De Herdt. E. and Kondo, M. (1981) Eur. J. Biochem. 117. 111-120

47 Barrieux, A. and Rosenfeld. M.G. (1979) J. Biol. Chem. 254, 8087-8090

48 Vincent, A., Goldenberg. S., Scherrer, K. (1981) Eur. J. Biochem. 114. 179-193

49 Schmid, H.P., Köhler, K. and Setyono, B. (1982) J. Cell Biol. 93, 893-898

50 Schmid, H.P., Köhler, K. and Setyono, B. (1983) Mol. Biol. Rep. $9.87-90$

51 Schmid, H.P., Schönfelder. M., Setyono, B. and Köhler, K. (1983) FEBS Lett. 157, 105-110

52 Butcher, P.D. and Arnstein, H.R.V. (1983) FEBS Lett. 153. 119-124 